\title{
BATI KAVŞAĞINDA ŞİNASİ VE DURUŞU
}

\author{
Şinasi And His Attitude At The Western Junction
}

Abdulhalim AYDIN ${ }^{1}$

"Diyar-ı küfrü gezdim beldeler kaşaneler gördüm, Dolaştım milk-i İslam'ı, bütün viraneler gördüm. "

Ziya Paşa

\begin{abstract}
Özet
Türk toplumunun Batılılaşma serüveni Osmanlı devletinin Batılı devletler karşısında siyasi, ekonomik, askeri alanlardaki geri kalmışlığı nedeniyle başlar. Hareketin en anlamlı ve düzenli süreci ise 1839 'daki Tanzimat fermanıyla gerçekleşir. Tanzimat hareketiyle Türk toplumunun Batı'yla olan ilişkileri her alanda olduğu gibi sanat ve edebiyat alanında da ivme kazanır. Yeni bir insan ve dünya algısı, yeni bir edebi duyuş ve ifade dönem aydınlarının büyük ilgisini çeker. Dönemin önemli aydınlarından Şinasi'nin batılılaşma hareketine olan katkısı önemsenecek kadar büyüktür. O, Batının insan ve dünya algıIsı üzerinde durarak özellikle XVIII. yüzyıl Fransız aydınlanmacı yazarlarını izlemiş ve bunların rasyonalist düşünceleri üzerinde yoğunlaşmıştır. Böylece Tanrı, insan, dünya, yaşam gibi temel konularda yeni bakış ve düşünceler geliştirerek Eski'nin karşı tarafinda konumlanır. Metafizik konularda bile akıl ve mantığını kullanan bir "bu dünya insanını" salık vermeye çalışır. Gerek şiirlerinde, gerekse makalelerinde yenilik adına, dilde olmasa da, düşünsel bağlamda önemli değişimler yapmıştır. Fransa'da kaldığ 1 yıllarda bir asır önce yaşamış aydınlanmacı yazarlarla ilgilenmesi onun Batılılaşmadan neyi anladığına ve hangi zihinsel programla gittiğine işaret eder. Batıllıaşmayı toplumsal değişim ve dönüşü̈m olarak gören Şinasi, kendi tarihsel şartları içinde ciddi sayılacak katkılar sağlamıştır.
\end{abstract}

Anahtar kelimeler: Batılılaşma, Şinasi, Tanzimat Hareketi, 18. Yüzyıl Fransız Aydınlanmacıları

\begin{abstract}
The westernization of Turkish society starts with the situation of Ottoman Empire's backwardness against western countries in the fields of politics, economy and military. The peak of the movement is in 1839 with the Rescript of Gülhane. With the Rescript of Gülhane, beside all the other fields, in literature and arts, relations has gained momentum with the West. New perceptions of human, new literary perceptions and expressions attracted the intellectuals of the era. One of the prominent figure of the intellectuals of the era, Şinasi has contributed in great deal to westernization. By focusing on the human and world perception of the West, he stressed the rationalist thoughts of XVIII. Century French intellectual writers. By doing this, he developed new approaches and ideas to basic issues such as human, God, life and the world and positions himself against old tradition. Even in metaphysical matters, he favors a 'today's human' who uses his mind and intellect. In his poems and articles he made remarkable chances,-maybe not in terms of language but- in terms of thought. During his stay in France, his interest in intellectuals a century before reveals what he understands from westernization. Seeing westernization as social change and transformation, Şinasi contributed remarkably in his own account to the movement.
\end{abstract}

Key words: Westernization, Şinasi, Tanzimat Movement, 18th Century French Writers.

\section{Tanzimat Öncesi Osmanlı Toplumunun Genel Durumu ve Tanzimat Dönemine Geçiş}

Türk toplumunun çağdaşlaşma, yenilenme veya batılılaşma adlarıyla anılan değişim süreci uzun sayılabilecek bir zaman önce başlamıştır. Yenilenme macerasını başlatan asıl neden Osmanlı Devletinin Batı toplumları karşısında siyasi, ekonomik, askeri alanlarda gittikçe gerilemesi olmuştur. Bu olumsuz gidişi önlemek, İmparatorluğu eski güçlü dönemlerine yeniden kavuşturmak için XVII. yüzyıldan başlayarak birtakım sslahat hareketlerine girişilmiştir. Ancak yapılan bu ıslahat hareketleri (Celâli ayaklanmalarının bastırılması, IV. Murat'ın ağır cezalandırmaları ve özellikle Köprülüler dönemindeki olumlu gelişmeler) çoğunlukla kişilerle sınırlı kaldığı ve sistem

\footnotetext{
1 - Prof. Dr., Fırat Üniversitesi İnsani ve Sosyal Bil. Fakültesi Batı Dilleri ve Ed. Böl. ELAZIĞ. halimaydin@gmail.com
} 
değişikliğini hedef almadığı için bir müddet sonra aynı sıkıntılar yeniden baş göstermiştir. ${ }^{2}$ XVIII. yüzyılda sadece disiplinin sağlanmasıyla düzelmenin sağlanamayacağı anlaşılmış, sistemle ilgili bir takım düzenlemelerin yapılması gerektiği anlaşıldığından bir dizi yenilik hareketine girişilmiş: Lâle Devri, I. Mahmut ve III. Selim dönemindeki reform hareketleri. XIX. yüzyılda imparatorlukta 1slahat hareketleri iyice hızlanır. Yeniçeri Ocağı kaldırılır, Mustafa Reşit Paşa'nın öncülüğünde Tanzimat Fermanı 3 Kasım 1839'da, Islahat Fermanı ${ }^{3}$ da 1856'da ilan edilmiştir. Görüldüğü gibi, bu hareket tümüyle yukarıdan aşağıya doğru inen, yani yönetim tarafindan halka sunulan bir yenilenme projesidir ${ }^{4}$. Bunun devlet eliyle yapılmasının en büyük nedeni ülkenin içinde bulunduğu askeri, siyasi ve ekonomik durumu iyileştirme çabasıdır.

Tanzimat Fermanı, Osmanlı devlet yönetiminde ve hukuk sisteminde Avrupai nitelikte bir takım düzenlemeler ve yenilikler manifestosudur. Bu fermanla toplumsal yaşamda Batı'ın örnek alındığı yeni bir dönem başlamış oluyordu. Böylece Osmanlı İmparatorluğu, yüzyıllardır mücadele ettiği Batılı toplumların medeniyet dünyasına girdiğini ve değerlerini benimsediğini ilan ediyordu. ${ }^{5}$ Öte yandan, bu dönemde alt yapısı az çok olgunlaşmış, Batı kültür ve uygarlığını almaya hazır bir Osmanlı seçkin tabakasının varlığından da söz edilebilir. Belli bir süreden beri bir kısım aydınımızın ve devlet adamımızın çabalarıyla Osmanlı toplumunda Batı uygarlığını benimseyecek bir alt kültür birikimi oluşmuştu. Bu kültüre sahip sınıf ezici bir üstünlükle sanat, edebiyat ve devlet adamı çevresinden oluşuyordu. Kısaca, hareketin başında Kenan Akyüz'ün de belirttiği gibi samimi, idealist ve aydın bir nesil yer alıyordu ve yine bu aydın sinıfin inisiyatifiyle hareket halka mal edilmeye çalış1lıyordu. ${ }^{6}$

Tanzimat Fermanının içeriği, bu hareketin 1789 İhtilalinden ve genel anlamda Fransız kültür ve uygarlığından ne tür etkiler taşıdığını göstermesi bakımından kayda değerdir. Bu fermanda, Osmanlı devletinin yüz elli yıldan beri (1699-1839) yaşadığı olumsuzlukların nedeninin kanunlara saygısızlık gösterilmesinden olduğu, ülkenin kalkınması için yeni yasaların konması gerektiği anlatılmış, bunun için yeni düzenlemeler yapılmıştır. Kanun önünde padişah dahil herkesin eşit olacağı hukuki düzenlemeler yapılmıştır. ${ }^{7}$ Ferman için Fuat Köprülü: «Bu devrin ve bu devir edebiyatının yalnız fikrî cephesini göz önüne alırsak, bu ideolojinin doğrudan doğruya büyük Fransız İhtilali'nin yaydığı prensiplerden ve XVIII-XIX. asır Fransız edebiyatından alınmış olduğunu açıcça görürüz» demektedir. ${ }^{8}$ Hatta Fermanla ilgili o dönemde çıkan Le National gazetesinde, bu hareketin 1789 Fransız ihtilaliyle bir karşılaştırması yapılarak Tanzimat'ın kaynağının Fransız devrimi olduğu yorumu yapılmıştır. ${ }^{9}$ İdari ve hukuki alandaki bu yeniliklere paralel olarak eğitim ve kültür alanında da önemli gelişmeler kaydedilir: okullar, gazeteler, Encümen-i Daniş gibi kurumlar ihdas edilir.

1839-1878 yılları arasında kalan dönemin en belirgin özelliği, Osmanlı İmparatorluğu'nun Batı'ya, Batı'nın da Osmanlı İmparatorluğu'na iyice yakınlaşması ve Batı hayranlığının toplumumuzun geniş tabakalarına doğru yayılmaya başlamasıdır. Tercüme Odası'nın da zihniyet değişimindeki rolü büyük olmuştur. Fransız matbuatından yapılan siyasi, edebi ve kültürel ağırlıklı

\footnotetext{
2-Enver Ziya Karal, "Tanzimattan Evvel Garplılaşma Hareketleri", Tanzimat I., Maarif Mtb. İst. 1940, s.15-16.

3-1856 Islahat Fermanı, Abdülmecid'in sadrazamı Mehmet Emin Paşa'yı muhatab alarak "memleket dahilinde icrası icap eden muhtelif hususatı tesbit ve bunların ifa ve icrasına" denilerek 1839 Tanzimat Fermanında belirtilen ve yerine getirilmemiş bazı hususların yeniden gündeme getirilmesi, ayrıca aynı fermanın bu fermanla daha da genişletilmek istenmesi amacıyla hazırlanmıştır. Daha çok yabancıların baskısıyla ilan edilen bu fermanla azınlıklara daha önce tanınan hakların sınırları genişletilmiş, böylece İmparatorluk içinde Avrupa devletlerinin nüfuzu daha da artmıştır. Daha fazla bilgi için bkz. Recai G. Okandan, “Amme Hukukumuzda Tanzimat Devri”, Tanzimat I., ss.114-115.

${ }^{4}$-Recai G. Okandan, agy., s.114.

5_Osman Nuri Ekiz, Şinasi, Kastaş yay., İst. 1985, s.12.

6-Kenan Akyüz, Modern Türk Edebiyatının Ana Çizgileri, İnkılâp Kitapevi, İst., 1990, s.23

7-Daha fazla bilgi için bkz. Agah Sırrı Levend, Edebiyat Tarihi Dersleri-Tanzimat Edebiyatı, Marifet Mtb., İst. 1934, ss. $9-12$

8- Ord. Prof. M. Fuat Köprülü, Edebiyat Araştırmaları I., Ötüken, İst. 1989, s.299.

9-Daha fazla bilgi için bkz. Sabri Esat Siyavuşgil, "Tanzimat'ın Fransız Efkârı Umumiyesinde Uyandırdığı Akisler", Tanzimat I., ss. 751-752.
} 
tercümeler Türk toplumunun Batı kültür ve uygarlığı hakkında daha fazla bilgi sahibi olmasına yol açmış. Burayı bir "mektep"e benzeten Tanpınar, Tanzimat'ın ilanıyla beraber bu odanın yalnızca gençlere Fransızcayı öğretmekle kalmadığını, aynı zamanda yeni bir dünya görüşünün, yeni bir siyasi idealin geliştiği çok ileri bir çevre olduğunu vurgular. ${ }^{10}$ Tüm bu gelişmelere rağmen, şunu da belirtmek gerekir ki, Tanzimat'ın ilk dönemlerinde batılılaşma kavramı şekilcilikte kalmış, düşünsel ve edebi alanlarda çelişki ve yanılgılara düşmekten kaçınılamamıştır. Yeniliğin yalnızca Batı'daki cari düşünceleri ve hazır malzemeyi taşımakla gerçekleştirilebileceğine inanan Yeni Osmanlılar, Batı toplumunun yüzyıllar sonunda elde ettikleri tarihsel, siyasal, ekonomik nitelikli kazanımlarını göz ardı etmişlerdi. Bu ise, Batılılaşma hareketini eski-yeni, milli-yabancı gibi tartışmaların yaşandığı problematik bir alan haline getiriyordu.

$\mathrm{Bu}$ toplumsal değişimler edebiyat alanında da kendini göstermekte gecikmez. Batı kültürüyle yetişen yeni nesil, eski edebiyatın yeni yaşamı ifadeye elverişsiz olduğunu görür ve Batı edebiyatı yolunda yeni bir edebi anlayış açmaya girişir. Tanzimat Edebiyatı adı verilen bu devirde eski edebiyat gittikçe gerilemiş, buna karşılık yeni edebiyat ilerlemiştir. Batı edebiyatının Türk edebiyatına geçişi büyük ölçüde Avrupa'ya daha doğrusu Fransa'ya giden ya da oraya kaçan düşünce, edebiyat, siyaset ve devlet adamlarımızın gayretleriyle olmuştur. Yirmi Sekiz Mehmet Çelebi, Mustafa Reşit Paşa, Şinasi, N. Kemal, R. Ekrem, A. Hamid, Cevdet Paşa, A. Vefik Paşa, Şemseddin Sami gibi pek çok aydınımız ya Avrupa'daki memurluk yaşamlarında Batı edebiyatını okumuş, öğrenmiş ya da ülkedeki Tanzimatçılarla sıkı ilişkiye girerek Batı dünyasını öğrenmeye çalışmışlardır. Ayrıca, bu yılda bolca tercüme faaliyeti yapılır. Şinasi; Racine, Moliere, Lamartine, Lafontaine, Gilbert ve Fenelon'dan yaptığı tercümeleri “Tercüme-i Manzume" adıyla yayımlar. Şinasi "Şair Evlenmesi”ni bu yıl yazar, Y. Kamil Paşa'nın ve Münif Paşa'nın Fransız edebiyatından yaptıkları tercümeler de bu yıla, yani 1859'a rastlar.

\section{Batıya açılırken niçin ilk kapı hep Fransa olmuştur? Neden Fransız etkisi?}

Bunu bir kaç nedene bağlamak mümkündür. Önce tarihsel olayların etkisiyle oluşan FransızOsmanlı dostluğu bu kapıyı ilk defa olarak açar. ${ }^{11}$ Fransa kralı François I. Pavie'de İtalyanlara tutsak düşüp Kanunî'den yardım ister. Kanuni'nin yardımıyla hem özgürlüğüne, hem de tahtına kavuşur. Bu olay, geleneksel Türk-Fransız kültürel ilişkilerin başlangıcı sayılabilir. Öte yandan, XVII. yüzyılda Fransız dili ve kültürü Avrupa'da en yaygın durumdaydı. Fransız İhtilali'nin yaydığı fikirler yeni yetişen kuşak üzerinde büyük etkiler meydana getirmişti. Tanzimat Fermanındaki fikirlerin yansımaları bunu gösterir. Fransız filozof ve edebiyatçılarının görüş ve düşüncelerinde yenilikçi Türk aydınının aradığı özellikler vardı: özgürlükçülük, akılcılık ve uygarlık. Bu yüzden Fransız yazarlarının eserlerinde tasvir edilen dünya, Tanzimat aydınlarının düşledikleri dünyayla örtüşüyordu. Bunun dışında, Fransız edebiyatının Batı edebiyatı içindeki parlak ve egemen durumu, dikkat ve ilgiyi bu ulusun edebiyatına çeviren bir başka etken olmuştur. Nitekim Batı'dan yapılan ilk edebi çeviriler Fransız edebiyatından olur. Tanzimat aydınları, özellikle XVII., XVIII. ve kendi çağdaşları olan XIX. yüzyıl yazarlarını eserlerinden izleyerek bu ulusun düşünsel ve edebi anlayışını kavramaya çalışmışlar. Hoca Tahsin Efendi'nin şu beyti, Fransa'nın durumunu ve aydınlarımızın bu ülkeye olan bakışını özetler:

"Paris'e git bir gün evvel, akl u fikrin var ise,

Aleme gelmiş sayılmaz gitmeyenler Paris 'e."

\section{Şinasi’nin Katkıları}

"Batı'ya açılan ilk penceremiz"12 olarak anılan Şinasi’nin bu uygarlık değişimi projesindeki rolü büyük olmuştur. Şinasi'nin eserlerinde öne çıkan asıl şey sanatsal nitelik değil, verdiği yeni mesajlar, duruş ve düşünceleridir. Düşünce sistemi akıl ve mantığa dayanan Şinasi'nin Batılılaşma yolundaki çabaları hem makaleleri hem de şiirleri yoluyla olmuştur. Yazılarında medeniyet, hak,

\footnotetext{
10-Ahmet Hamdi Tanpınar, 19. Asır Türk Edebiyatı Tarihi, Çağlayan Kitabevi, İst., 1997,s.143.

${ }^{11}$-Enver Ziya Karal, agy, s.30.

12-Daha fazla bilgi için bkz. Prof. Dr. Gündüz Akıncı, Batıya Yönelirken Şinasi, DTCF yay. Ank. 1966.
} 
hukuk, adalet, kanun, akıl, vatandaşlık hakları gibi sosyal ve siyasal kavramları dile getirmiş, gazete aracılığıyla halkı bilinçlendirmeye çalışmıştır.

Kuşkusuz Şinasi'nin bu tutumunu ve yenilik arayışını Fransa'da kaldığı yıllarda edindiği bilgi ve kültürün bir yansıması olarak değerlendirebiliriz. Burada kaldığı yaklaşık dokuz-on yıllık bir sürede ${ }^{13}$ Fransızcayı çok iyi öğrendiği, belli başlı Fransız yazarlarının çoğunu okuduğu ve oryantalist de Sacy ailesi ve Pavet de Courteille'le, Lamartine'le tanıştığı onun toplantılarına katıldığı, E.Renan ile tanıştığı ve dilbilimci Littré ile sıkı dostluk kurduğu bilinmektedir. ${ }^{14}$ Littré'nin etkisiyle eski alfabeye göre "t" harfine kadar gelen bir Türkçe sözlük yazdığı da anlaşılmaktadır. ${ }^{15}$ Fransız düşünüş ve edebiyatıyla olan bu ilişki, bu ulusun kültür ve uygarlığının yazarımız üzerinde bir düşünce sisteminin belli başlı çizgilerinin oluşmasına rehberlik edecektir. Nitekim o, Kemal ve Hamid gibi belli bir yazar ve edebi okula bağlanmamış, düşünce ve edebiyattaki etkilenme yelpazesi geniş bir alana yayılmıştır. Düşünsel ve siyasal görüşlerinin oluşumunda Fénelon, Voltaire, Montesquieu, Rousseau ve hatta Compte'un kimi görüşlerinden yararlanarak yeni bir topluma gidecek ana çizgileri belirlemeye çalışmış. Edebiyatta da Racine'den başlayıp Hugo ve Lamartine'e kadar bir dizi yazarı tanımaya çalışış, benzemek yerine onlardan bir edebiyat dersi alma yoluna gitmiştir. Tanpınar bunu, "o, garptan falan ve filan muharririn değil, bir medeniyetin ve düşünce sisteminin dersini almıştır" sözleriyle ifade eder. Batı'dan gazeteciliği getirirken de bireyi ve toplumu bilgiyle donatmak istiyordu. Böylelikle, modeli "Batı olan kurulacak yeni bir uygarlığın içini eski malzemeden arındırmak" istiyordu. Mehmet Kaplan da Şinasi'nin gerek düşüncede, gerekse şiirde yaptığı yenilikleri "Fransa'da tahsil görmesine ve XVIII. yüzyıl yazarlarını okumuş olmasına" bağlar. ${ }^{16}$ Şinasi'nin Avrupa'dayken gördüğü yeni düşünce ve uygarlık ölçütlerini kendi ülkesinde de uygulamak istemesi, onu gazeteciliğe yönlendirmiştir. Çünkü olabilecek en geniş biçimde halka ulaşmak ve Batı kültür ve uygarlığını tanitmak ancak gazete yoluyla mümkündü. Çoğu zaman Şinasi ve Kemal'in gerek gazete ve gerekse bazı tiyatro eserlerinin başına "bil-iltizam lisan-1 avam üzre yazılmıştır" veya "giderek umum halkın anlayabileceği" gibi uyarılar yazmalarının temelinde Şinasinin başlattığı bu Halkçıl1ı ${ }^{17}$ hareketini, sarayda hapsolmuş ya da onun tekeline girmiş bir sanat ve edebiyatı kurtarma ve halka yayma operasyonu olarak algılayabiliriz.

"İstanbul sokaklarının tenvir ve tathiri" adındaki yazısında Şinasi, İstanbul için, «...öyle bir dârülmilk ki zamânemizde Asya'nın akl-i pîrânesi Avrupa'nın bikr-i fikri ile izdivaç etmek için bir haclegâh olmuştur» ${ }^{18}$ (Öyle bir başkent ki zamanımızda Asya'nın gün görmüş (olgun) aklı, Batı'nın yepyeni düşünceleri ile birleşecek bir yerdir) demektedir. Kuşkusuz ki Şinasi bu sözleriyle, insanlık tarihiyle eş zamanlı olan Asya bilgeliğinin yeni bir bakış, yeni bir solukla bir ivme kazanması, bir bakıma ötekiyle tanışması gerektiğini anlatmaktadır. Asya'nın derin bilgeliğinin, Batı'nın rasyonalizm ve pozitivizmle beslenmiş yeni düşünce sistemine ihtiyaç duyduğuna inanır. Böyle bir süreçte Şinasi Türkistan diye adlandırdığı Türkiye için bir görev biçiyor: Doğu ve Batı uygarlıkları arasında bir buluşma köprüsü, bir uzlaşı noktası. Şinasi'nin bu 'evlilik'ten beklediği, Şarkın engin bir yaşam deneyimi ve bilgeliğinin yanında, Garbın pozitif bilimler ışığı altında, yenilikçi, akılcı ve gelecekçi bir anlayıştan doğacak bir çocuktur. Kökü geçmişinde ve benliğine bağli; gözleri de gelecekte, parlak ve umutlu. Şinasi'nin bu düşünceleri daha sonra Yahya Kemal'in dilinde

\footnotetext{
13-Bu süre 1849-1854; 1865-1867; 1867-1869 yılları arasındaki aralıkları kapsar. Bunun için bkz. Nihad Sami Banarlı, Resimli Türk Edebiyatı Tarihi C.II, MEB. Yay., İst.,1998, ss. 860-61; Osman Nuri Ekiz, agy, ss.40-44.

14-Daha fazla bilgi için bkz. Ahmet Hamdi Tanpınar, Agy, s. 189; Hüseyin Seçmen, Şinasi, TDK. yay., Ank.1972; Nihad Sami Banarl1, agy.,C.II.; Orhan Köprülü, Türk Klasikleri, Dösar yay., İst., 1984, s.7.

${ }^{15}$-Bkz. Ahmet Hamdi Tanpınar, agy., s. 190; Banarlı, agy, s. 868; Kenan Akyüz, Batı Tesirinde Türk Şiiri Antolojisi, İnk1lap Kitapevi, İst.1986, s.4. Bu yazarlara göre, sözlügün herhangi bir nüshası bulunmamaktadır. Hilmi Ziya Ülken ise, bunun aslının Fransız Ulusal Kütüphanesinde (Bibliothèque Nationale) bulunduğunu söylüyor. Bunun için bkz. H.Z.Ülken, Türkiye'de Çağdaş Düşünce Tarihi, Ülken Yay., İst.1998,s.65.

16 - bkz. Mehmet Kaplan, "Şinasi'nin Türk Şiirinde Yaptığı Yenilik”, Türk Edebiyatı Üzerine Araştırmalar, İst.1999, s.274.

${ }^{17}$-Şinasi'nin halkçıllı̆̆ için bkz. Enver Ziya Karal, Osmanlı Tarihi, C.VII. TTK Ank. 1956, s.321.

18_Şinasi, Makaleler, Külliyat, IV. Baskıya hazırlayan Fevziye Abdullah Tansel, Dün-Bugün yay., Ank. 1960.
} 
"mektep" olacak; ancak şair bir önemli noktaya dikkat çekerek burada kalmamayı ve mutlaka "memlekete dönmeyi" "19 salık verecektir. Belirtmeli ki, Yahya Kemal'in bu ufuk açıcı ve tayin edici tespiti eğer örneğin 70-80 sene evvel söylenmiş olsaydı, belki ne eski-yeni kavgası bu kadar şiddetli olurdu, ne de kimi aydınımızın Avrupa'nın sanat, edebiyat, bilim..vb. alanlardaki gelişmişliğini övmek adına burayı yüceltip kendi yurdunu alçaltmak; aklıyla, fikriyle, tutum ve edimleriyle burada kalmak zehabına düşmüş olurlardı.

Şinasi'nin Batılılaşma düşüncesinde asıl üzerinde durmak istediği nokta burada gördügü "insan" telakkisidir. Batının Hümanizmadan beri alıp işlediği insan, çok yol almış ve skolastik düşüncenin "köle insan" anlayışından uzaklaştırarak yeryüzü yaşamının merkezine oturtulmuştu. Aynı zamanda bireysellikte de büyük aşamalar kat etmiş bu insan, değerli, akıl ve irade sahibi, düşünen, eyleyen ve saygıya değer bir varlık olarak yüceltilmiştir. İnsan merkezli bu hümanist felsefe, 18 yüzyıl aydınlanmacıların ellerinde hukuk, adalet, siyaset, düşünce alanlarına kadar yayılarak rasyonalist bir bakış ve felsefeyle derinlemesine geliştirilmiştir. Böylece daha 2-3 asır öncesinin skolastik zihniyeti ve yoz insan düşüncesi yerini aydınlanmacı ve ilerici insan algısına bırakır. "İnsan, doğuştan birtakım doğal haklara sahiptir ve her şey insan için vardır" düşüncesi egemen kılınmaya başlar. Şinasi'nin gördüğü bu yeni insan telakkisi, alışık olduğu eski insan algısından çok farklıydı. Kaderci, kul, tevekkül eden, olaylara ilahi hikmetle bakan ve bu dünyaya önem vermeyen eski insan yerine o, bize düşünen, aklını kullanan, sebeplerin peşinden koşan ve bu dünyayı ve hayatını değerli sayan bir insan tipini sunmaya çalışır. Gözü gökte değil, yeryüzünde olan bir insandır bu. ${ }^{20}$ Yapmaya çalıştığ 1 şey Doğu medeniyetinden Batı medeniyetine geçmektir. $\mathrm{Bu}$, insan ve onun yaratımları üzerinde yükselecek bir medeniyettir. İşte bu yüzdendir ki, yazdığı şiirlerinde pek çok defa akıl, adalet, medeniyet, hak gibi kavramlar geçmekte ve tüm bunlarda yegane amil güç olarak insan merkeze alınmaktadır. Bu insan, yeni medeniyeti inşa edecek olan insandir.

Şinasi'nin Batı'dan esaslı olarak aldığı kavramların başında "akılcılık" (rationalisme) gelmektedir. Hilmi Ziya'ya göre, onun Batı dünyasından almak istediği şey "akıl ve kanun" kavramları etrafinda yoğunlaşmıştır. ${ }^{21}$ Çünkü Şinasi'ye göre, Batı'nın ulaşmış olduğu uygarlık seviyesi akılcılığa verdiği önemden gelmektedir. Reşit paşa için yazdığı kasidede akıl kelimesi 11 kez geçer. Şairin bu kavrama fazlaca önem vermesinin temelinde geleceği inşa edecek olan insan telakkisinin yanı sıra, Batı dünyasının bu kavrama vermiş olduğu önemle de yakından ilgilidir. Akıl, eskiler (Divan Ed.) tarafından kimi konularda yetersiz görülmüş ve hak etiği yeri alamamıştı. Onun Tanrı'yı anlamasına imkan yoktur. Çünkü eskiler için Tanrı'nın varlığı açık bir hakikattir. Bunu ispata çalışmak hem abes, hem de günahtır. Şinasi ise, "vahdet-i zatına aklımca şehadet lazım" diyerek geleneğin dışına çıkar ve Tanrı'nın varlığına inanması için aklının kabul edeceği birtakım delillere ihtiyaç duyar. Bu tavrında, Batı rasyonalizminde önemli yere sahip olan Voltaire başta olmak üzere XVIII. yüzyıl filozoflarının "doğal din" anlayışının açık etkileri muhakkaktır. Örneğin Tahmid'de şair bir yandan yeni insan algısını ortaya atarken, bir yandan da onun Tanrı karşısındaki duruşunu verir. Kendisine verilen akılla Tanrı'yı bulan insan yine diğer vergiler olan kalp ve dil ile O'na doğru gitmeye devam eder. Yalnızca bu beyitte bile akıl ile diğer iki enstrümanın sentaksik pozisyonu onun tanrı arayışında akla verdiği önemi belirtmesi bakımından dikkate değerdir. Tanrı arayışında akıl, doğal fonksiyonu gereği a priori düşünmek( fikretmek), yani varlığı, eşyayı sorgulamak üzere devreye girer. Buradan gelen ikna edici veriler ve deliller sonucunda ise kalp inanmakla şükür eylemini, lisan da zikir eylemini icra eder. Yani şair, kulluğunun gereği olan şükür ve zikir eylemlerini akıldan gelecek delil şartına bağlamış görünüyor:

Değil mi Tanrı'nın ihsânı akl-ü kalb-ü lisan,

Bu lûtfu etmelidir fikr-ü şükr-ü zikr insan.

Voltaire evrenin büyük düzeni ve sistemin kusursuz çalışması karşısında "Tanrı olmasaydı,

19 - Yahya Kemal, Edebiyata Dair, İstanbul Fetih Cemiyeti Yay., İst., 1990, s. 139.

20 - Mehmet Kaplan, “Şinasi’nin Türk Şiirinde Yaptığı Yenilik”, Türk Edebiyatı Üzerinde Araştırmalar, İst, 1999, s.258.

${ }^{21}$ - Bunun için bkz. Hilmi Ziya Ülken, Türkiye'de Çağdaş Düşünce Tarihi, Ülken yay., İst.1998, s.66. 
onu yaratmak gerekirdi" diyerek ak1l yoluyla Tanrı'yı bulur. Buna benzer akıl yoluyla Tanrı'ya ulaşma düşüncesi Münacaat'ın pek çok yerinde geçer. Örneğin, benzer bir duyuş ve düşünüşle varlık sisteminin muazzam çalışması ve ilişkileri karşısında şair, tüm evreni gögüslemeye gerek duymadan küçücük bir zerreden yola çıkarak yine akıl yolu ile ona ulaşır:

Varlığın bilme ne hâcet küre-i âlem ile.

Yeter isbâtına halk ettiği bir zerre bile.

Öte yandan, Batı'nın Aydınlanma düşüncesinin şekillenmesinde önemli bir yer işgal eden Voltaire'in düşünceleriyle Şinasi'nin paradigması arasında önemli benzerlikler görmek mümkündür. Bunu derken Şinasi’nin onu birebir izlediğini kastetmiyoruz. Belirtmek istediğimiz şey, bu Fransız yazarının düşünceleri genel anlamda Batı'nın aydınlanmacı ruhunu yansıttığından, yazarımızın bu genel bakış ve yaklaşımdan etkilendiği dahası bu olguyu bakışının odağına yerleştirdiği gerçeğine vurgu yapmaktır. Bu bağlamda, Voltaire'in bu gibi konulardaki görüşlerinin belirtilmesi bir bakıma bu çağın genel karakteristiğinin yansıtılması anlamına gelecektir. İster Voltaire, ister, Rousseau, ister Descartes olsun, kısaca Batının aydınlanmacı düşüncesinden hareketle Şinasi'nin yapmaya çalıştığı şey bir zihniyet değişimi çerçevesinde anlaşılmalıdır. Bunun en büyük delili metafizik konularda soyuttan somuta, ahiretten dünyaya, kalp ve ruhtan akla doğru giden bir çizgiyi esas almasıdır.

Varlık aleminin kusursuz işleyişi ve düzeni karşısında düşünen, gören, ilişkiler çıkaran ve bununla diyalektik bir sonuca ulaşan bilinç ve akıl sahibi insanın, Voltaire'e göre ulaşacağ 1 tek nokta tüm varlığın sahibi ve kurucusu bir üst varlığa, Tanrı'ya ulaşmaktan başka çıkışı yoktur. Varlık ve yaratılışı hakkında çeşitli mülahazalara giren Voltaire, Tanrı'ya ulaşmada genel anlamda iki yol olduğunu, bunların akıl ve metafizik yöntemle mümkün olduğunu söyler. Ak1l yoluyla evren ve varlık hakkında çıkarsamalara giderken diyalektik bir tutum izleyerek örneğin en yakından, insandan yani kendisinden başlar. Dokuz ay süreyle insanın rahimde yaşamsallığını sürdürmesine imkan sağlayacak tüm enstrümanlara sahip olması üzerinde durur. Ama yalnızca bu argümanla bir neticeye varamayacağını düşünür. Çünkü sonrasında görmek için gözle, tutmak için elle ...vb tüm cihazlarla donatılması iki ihtimali akla getirir. Ya tüm bunları kendisi tasarlamış ve yapmıştır. O zaman da "yok"tan bunları meydana getirmesi gerekirdi. Bu durumda insanın her anlamda sonsuz güce sahip olması gerekecekti. Bu noktada Voltaire, şu yargıya varır ve ikinci ihtimali dile getirir: "O halde, benden çok daha kudretli bir varllğın eseri olmam gerekir; bu varlık ezelden beri olmalıdır. O her şeyi yaratmış olmalı ve sonsuz olmalıdır." 22 Fransız filozofunun bu düşünceleri, Şinasi'nin diğer güçlü delilleri bir yana bırakarak yalnızca kendi varlığından hareketle Tanrı varlığına ulaştığı aşağıdaki beytindeki metodla aynı noktada buluşur:

Varlığım Hâlik'in varlığına şâhittir

Gayrı burhân-1 kavî var ise de zâittir ${ }^{23}$

Bilinçli süje sıfatıyla insan, kendisi için bir bilgi objesi olan varlık ve eşya karşısında henüz felsefi ve metafizik bir alana girmeden yalnızca epistemolojik anlamda, başka deyimle, özne nesne ilişkisinin ilk ve yalın basamağı olan bilginin edinmesiyle bile kuşatıcı bir yüce varlığın bilgisine ulaşır. Voltaire'in varlık ve yaratılış ile ilgili genel tutumu bu çerçevede olmuştur. Aşağıdaki dizeleri Şinasi'nin akıl yoluyla Tanrı'yı aramanın genel sistematiğiyle örtüşüyor. Bunlar başta Münacaat'ında olmak üzere diğer beyitlerindeki tanrı arayışı ve buradaki duruşuyla yakın ilişki içindedir:

L'univers m'embarrasse, et je ne puis songer

Que cette horloge existe et n'ait point d'horloger. ${ }^{24}$

(Bir saat misali öylesine kusursuz işleyen evren varsa, saatçisi olmadığını düşünemiyorum)

\footnotetext{
${ }^{22}$ Voltaire, Traité de Philosophie, Oeuvres de Voltaire, P. Pourrat Freres Ed., Paris, 1839, p. 128.

${ }^{23}$ Şinasi, Müntabahat-ı Eş'ar, Hazırlayan : Süheyl Beken, Dün-Bugün Yay., Ankara, 1960, s.11

${ }^{24}$-Voltaire, Les Cabales, in Euvres de Voltaire, P. Pourrat Freres Ed., Paris, 1839, p. 127.
} 
Eski edebiyatta ve gelenekte akla bu tür metafizik meselelerde görev verilmemiştir. Ancak Tanzimatla ve Şinasi'nin bu ilk septik üsluba dayanan hamleleriyle beraber, Tanzimat yazarları arasında bir akıl-ruh veya akıl-iman çatışması görülür. Şüphesiz ki bu tavır, bir imansızlık meselesi olarak değerlendirilmemelidir. Tavır ve bakışta bir değișiklik, duruş ve yöntemde bir yenilikti bu. Tanrı ve hakikat arayışındaki akılcı ve septik tutum, O'nu başka bir yolla aramanın ifadesiydi. Bu tutum ve yöntem değişikliğinin en temel nedeni, başta Şinasi olmak üzere Tanzimatçıların okumuş oldukları batılı düşünürlerin etkileridir. Bilindiği gibi Hümanizmayla ama daha çok XVIII. yüzyıl aydınlanmacıların kilisenin dogmatik ve baskıcı Tanrı inancını bir yana bırakarak akıl ve mantığı ölçüt almalarıyla başlayan rasyonalist, şüpheci ve araştırmacı bir arayış baş göstermişti. Akıl ve düşünce yoluyla her şeye ulaşılabileceği, sorunların aklın ölçüt alınmasıyla çözülebileceğine inanmışlardı. Voltaire, dünyayı açıklayıcı ilk ve zorunlu neden olarak aklı görür ve yine bu akıl sayesinde Tanrının varlığına ulaşır. Şinasi ve Hamid'in tavırları bu anlamda Batılı filozofların çizgisine yakın olmakla beraber, son tahlilde iman söz konusu olduğunda her defasında tüm sorgulamalarının sonunda Tanrı'nın önünde diz çökerken buluruz onları. Hamid'in "her nasılsa zihnimden geçti" dediği bu fikirlerin Şinasi'deki boyutu da bir inanç meselesinden çok akıl ve düşünceye verdiği önemi belirtmesi açısından kayda değerdir. Onunki, bir inançsızlık meselesi değildir; zaten iman ve itikat noktasında varlığından şüphe duymadığg tanrı düşüncesini akıl yoluyla buldurmak, bir bakıma rasyonalist bir tavırla diyalektik bir süreç sonunda O'na ulaşma, ispat etme gayretidir. Öte yandan, iman ve itikat noktasında varlığından hiç şüphe duymadığı Tanrı'yı akıl yoluyla buldurma çabasını, onun medeniyet değişimi projesine bir model sunma teșebbüsü olarak da düşünebiliriz: Tanrı'nın varlı̆̆ı gibi en hassas ve temel konuda akla başvurmada bir beis yok ise, diğer tüm dünyevi işlerimizde buna neden bir sakınca olsun? $\mathrm{Bu}$ şekilde, en can alıcı ve kuşatıcı meselenin akıl yoluyla halledilebilmesi, toplumsal değişim ve dönüşüm denebilecek varlığın, insanın, hayatın anlamlandırılmasında aynı metodun önünün kendiliğinden açılması demekti. $\mathrm{Bu}$ ise şu anlama geliyordu: Bireysel ve toplumsal tüm sorunlarımız bir akıl yürütmeyle, bir diyalektik süreçle çözümlenebildiğine göre, uygarlık değişiminde "akıl" şaşmaz bir metot olacaktı.

Onun akılcı ve mantıkçı bir yolla Batı'ya yaklaşmasının bir göstergesi de Voltaire, Montesquieu, Rousseau, Fenelon, Descartes gibi rasyonalist Fransız yazarları etrafinda dolaşması ve bunların eserlerinden tercümeler yaparak onların düşünce dünyasını anlamaya çalışmasıdır. Ayrıca klasik Fransız edebiyatından seçme metinlerin yer aldığı Tercüme-i Manzume adlı eserde Racine, La Fontaine, Gilbert, Fenelon'dan tercümeler yapmıştır. Onun bu dönemde cari olan Romantizme yönelmeyip bir asır öncesi yaşanmıș Aydınlanma Çağıyla meșgul olması bu bağlamda ilginçtir. 1849 yılında Fransa'ya ilk gittiğinde realizm doğum sancılarını yaşasa da bu tarihlerde dünya edebiyatını büyük ölçüde sarsan romantizmin etkileri devam etmekteydi. Ayrıca Hugo hala yaşıyordu ve tüm nüfuzu Fransa ve Avrupa'da sürmekteydi. Buna rağmen Şinasi’nin romantizme ve Hugo'ya ciddi anlamda iltifat etmemesi ve bir asır öncesi yaşamış filozoflardan yana seçim yapması onun Türk medeniyetinin bu dönüşüm noktasında hangi parametreleri esas aldığını göstermesi açısından son derece ilginçtir. Her ne kadar Hugo, Musset ve Lamartine gibi romantiklerden şiir çevirileri yapmışsa da, bu tavrı onun şiirde ve düşüncede gerçekleştirmek istediği değişimle ilişkili değildi. Bu, olsa olsa 1835 'lerde Hugo ve Vigny'nin büyük katkılarıyla sonradan gerçekleşecek olan romantizmin "toplumcu" yanıyla ilişkilendirilmelidir. Çünkü romantizmin kalın çizgisi olan lirizm ve santimantalizmin yanında, bu tarihten itibaren şaire toplumcu, hümanist ve moralist bir görev veren ve onu bir çeşit "mage" (büyücü) gibi gören, onu toplumsal sorunlarla karşı karşıya getiren bir misyon verilir. Bu açıdan bakıldığında, Şinasi’nin o günkü Batı toplumunun "dönüşüm kodlarını" doğru yerden okuduğunu söyleyebiliriz. İşte Şinasi'nin bu öngörüsü onu asıl yenilikçiliğgin başına getiren niteliğidir.

N. Kemal ve A. Hamid'e baktığımızda, yeniliklerinin çoğunlukla edebiyat alanında olduğu görülmektedir. Kemal'in kimi toplum ve bireyle ilgili makaleleri varsa da bunların -aralarındaki iliş̧kiden dolayı- Şinasi'nin etkisiyle yazıldığı muhakkaktır. Bu iki yazarın modernleşme ve değişimden anladıkları çoğunlukla edebiyat dairesiyle sınırlı kalmış ve kendi dönemleri için 


\section{F.Ü. Sosyal Bilimler Dergisi 2017-27/2}

Fransa'da çoktan sona ermiş olan romantik akımı büyük bir heyecan ve yenilik biçiminde alkışlayarak ülkeye sokmaya çalışmışlaradır. Oysaki bu tarihlerde, Kemal ve Hamid bu büyük heyecanları yaşarken, Fransa'da pozitivizmin ve sonra da daha katı tutumu olan determinizmin beslemesiyle realizm ve natüralizm rüzgarları en şiddetli biçimde esiyordu. Bu akım ve hareketler ise aslında tüm gücünü ve altyapısını bir asır önceki "aydınlanma dönemi filozoflarından" ve iki asır önceki "1660 Mektebi" denen klasik ekolden alıyordu. Tüm bunlar bize Şinasi'nin Batı'ya yönelirken şuurlu ve bilgili yaklaştığını gösterir. Her ne kadar sanatında ve eserlerinde bu yeniliği, örneğin Kemal ve Hamid'in romantizm için yaptıklarını yapamamışsa da, onun yeniliği ve batıcıllğı düşünce ve yol göstericiliğinde kendini daha çok hissettirir.

Aslında Şinasi ile Tanzimat edebiyatının bu iki büyük ismi arasında yapacağımız basit bir karşılaştırma bile onun yenilikten ne anladığını ve hangi pencereden gördügünü ortaya çıkaracaktır. Şairimizin anladığı yenilik veya batılılaşma genel anlamda bir toplumsal dönüşüm projesi olduğundan, Batı dünyasının Ortaçağ'ın skolastik zihniyetinden kurtuluşunu gerçekleştiren 18. yüzy1l filozof ve düşünürlerine yönelmiştir. $\mathrm{Bu}$ filozofların dünya algısı, akıl ve mantığın süzgecinden geçirilen bir dünyadır. Descartes'in “düşünüyorum, o halde varım” sözü Aydınlanma Çağının credo'su olmuştur. Öte yandan, kanun anlayışında Montesquieu'nün, toplumsal projelerde Voltaire'in, toplum eğitiminde (özellikle kız çocuklarının eğitimi, kadın hakları vb.) Rousseau'nun, tiyatro anlayışında (Şair Evlenmesi'nde Moliere'in Le Mariage Forcé ile Le Medecin Malgré Lui) Molière' in, ${ }^{25}$ Rasyonalizm' de Descartes ve Voltaire'in görüş ve düşünceleri Şinasi için bir model niteliğinde olmuştur. Ayrıca, unutmamalı ki bu yazar ve düşünürler Batı aydınlanmasının hazırlanmasında önemli görevler yapmışlardır. Bütün bunlara ek olarak Batı'da gerçekleşen Sanayi Devrimi, Fransız İhtilali ve bilimsel gelişmelerle pozitivizmin ivme kazanması yine Batı dünyasının hangi süreçleri yaşadığını ve nasıl bir insan ve medeniyet algısına doğru yol aldığını gösterir. Tüm bu yazar ve hareketlerin ortak yanı, yeni bir insan algısı oluşturmak ve yeni bir medeniyet kurmaktır. Şinasi'nin Fransa'ya gittiğinde belli bir zihinsel olgunlukta oluşu ve en azından Batı'yı anlamaya çalışırken hangi yönlerden yaklaşacağını biliyor olması, Batılı aydınlanmacılarına neden ve nasıl yaklaşacağının bilgisini de veriyordu. Onun bu aydın yazarlarla olan ilgisi yalnızca tercüme faaliyetiyle sınırlı kalmamış, aynı zamanda, onların düşünce dünyasını anlamaya çalışarak yaptıklarına paralel birtakım faaliyetlere girişmesine de neden olmuştur. Örneğin; Voltaire gibi sosyal projeler üzerinde durmuştur. Voltaire, sosyal, siyasal, ekonomik bir takım projeler geliştirmiş ve oturduğu Ferney bölgesi ticaret ve sanayi bakımından model oluşturacak kadar kalkınmış bir bölge olarak tüm civarın "cazibe" merkezi olmuştur. ${ }^{26}$ Paris sokaklarının yeniden düzenlenmesi, ışıklandırılması, temizlenmesi ve kanalizasyon şebekesinin kurulması konularında bir dizi proje hazırlamıştı. Şinasi de "İstanbul Sokaklarının Tenvir ve Tathiri" adında bir makale yazmış ve Voltaire'e benzer görüşler ileri sürerek İstanbul'un daha modern ve uygar bir görüntüsü için düşüncelerini belirtmiştir. ${ }^{27}$ Aynı şekilde, "Osmanlı Sanayi Sergisinin açılması"28 münasebetiyle yazdığ makalede ise, Osmanlı devletinin Avrupa'nın sahip olduğu sanayi kurumlarına ve ticaret merkezlerine bir an önce sahip olması gerektiğini yazar. Kanun hakkındaki görüşlerinin 1789 Fransız Devrimini hazırlayan düşünürlerden kaynaklandığı görüşü çoğunlukla benimsenen bir görüştür. ${ }^{29}$ Doğal Hukuk'tan devlet-birey ilişkisine kadar Şinasi genel anlamda Fransız düşünürlerinden etkilenmekle beraber kanun, yurttaşlık, hukuk, adalet, ulus, özgürlük konusundaki görüşleri Montesquieu'nün "Esprit des Lois" (Ruhul Kavanin) adlı eserinde geçen görüşlerle büyük paralellik göstermektedir. ${ }^{30}$ Aynı şekilde, Molière'in "Le Mariage Forcé"

\footnotetext{
25 - Bu piyesler arasındaki etki ilişkisi için bkz. Abdulhalim Aydın, "Şinasi’nin Şair Evlenmesi ’nde Fransız Etkisi” Fırat Üniversitesi Sosyal Bilimler Dergisi, Cilt: 11, S.1, ss.137-149 (2001).

${ }^{26}$-Bkz. Gustave Lanson, Histoire de la Littérature Française, Hachette, Paris, 1936,ss.388-415; Berke Vardar, Fransız Edebiyatı, Dönem Yay., C.III, İst., 1972, ss.45-61.

27-Şinasi, Makaleler, Külliyat, IV. Baskiya hazırlayan Fevziye Abdullah Tansel, Dün-Bugün yay., Ank. 1960.

${ }^{28}$-Şinasi, agm.

29 - Bunun için bkz. A. Hamdi Tanpınar, 19. Asır Türk Edebiyatı Tarihi, Çağlayan Kitabevi, ist, 1997; Hüseyin Seçmen, Şinasi, TDK, yay, Ank. 1972; N. S. Banarl, Resimli Türk Edebiyatı Tarihi, C.II.;

30 - Montesquieu, Kanunların Ruhu Üzerine, C.I., (Çev: Fehmi Baldaş), İst., 1963.
} 
(Zorla Evlenme, Zor Nikahı) adlı piyesinde söz-insan-akıl ile ilgili geçen "'La parole a été donnée à l'homme pour expliquer sa pensée; et tout ainsi que les pensées sont les portraits de choses, de même nos paroles sont-elles les portraits de nos pensées" şeklindeki ibare, adeta Şinasi tarafından manzum olarak yeniden yazılmış gibidir:

"Dilin irâdesini başta akl eder tedbir

Ki tercümân-1 lisandır anı eden takrîr

O tercümâna bedeldir kalem gehî elde

Eder tasavvurunû cism-i nâtıkın tasvir"

Öte yandan, Mustafa Reşit Paşa için beslediği büyük hayranlığı yalnızca Paşanın kendisini himaye eden tutumuyla değil, Batılılaşmada gösterdiği emekleri açısından açıklamak daha adilce olur. Birtakım tepkiler çeken "Aceb midir medeniyet resûlü dense sana" gibi sözler söylemesi, Paşa'nın Türk toplumuna yeni bir medeniyetin kapılarını açmış olmasıyla izah etmeli. Bu sayede toplumda adalet ve kanun hüküm sürecek ve kanun önünde herkesin eşit tutulmasıyla başta sultan olmak üzere herkese haddini bildirecektir. Hatta bu fermanla Türk yurdu batılılaşmayı başarırsa,

Ruma bir Avrupalı büt vereli revnak u şan

Reşk-i iklim-i Frenk olmadadır Türkistan

diyerek, Frenk elleri bile Türkiye'yi kıskanacak konuma gelecektir.

\section{Sonuç}

Genel bir çerçeve içinde düşündügümüzde, batılılaşma açısından Şinasi'nin edebiyatımıza getirdiği ve Kemal'in de bir miras gibi devam ettireceği yenilikleri şöyle toplayabiliriz: Toplumu yeni bir kültürle tanıştırmak, ona yeni kavram ve görüşler sunmak ve bunları gündemde tutarak yaşama daha çabuk girmesini sağlamak için gazete çıkardı. Öte yandan, yine gazeteyle halkın kendi sorunları üzerinde görüş alış-verişinde bulunmasını sağladı, yazdığı makalelerle de ya topluma bir yenilik önerdi ya da eskimiş olanı yıkmaya çalıştı. Şiirde fazla bir yenilik yapamadıysa da kimi küçük örneklerle yeniliği gösterdi. Biçime çok dokunmamakla beraber, şiirimizin içeriğini çeşitli sosyal kavramlarla doldurdu. Daha sonra, bu yeni dünyanın içine girip Batı tarzında ürünler verecek olan Hamid'e yol gösterdi. Batı şiirinden dilimize ilk çevirileri o yapar. Yeni nesrin temelini de o atar. Batı tarzında ilk tiyatro oyunumuzu yazmış (Şair Evlenmesi) ve bu alandaki gelenek onunla başlamıştır. Dilde yenileşmeyi başlatmış ve dili, üzerinde durulacak bir toplumsal dava haline getirmiştir. Bu alanda başlattığı hareketi Namık Kemal ve diğerleri sürdürürler. Ancak, dilde kendisi önemli bir aşama gerçekleştiremediği gibi ne Kemal ne de özellikle Ekrem ve Hamid açllan bu yolu geliştirememiş, aksine daha da eskiye götürmüşlerdir. Genel anlamda bütün düşünüş, davranış ve görüşleriyle halka inmiş, sanat ve edebiyatı halkın ve ideallerin hizmetinde görerek bir "halkçı" olmuştur. Bu noktada, Kemal'in sanat ve edebiyat anlayışı üzerinde önemli etkiler yaratmıştır.

\section{KAYNAKÇA}

Akıncı, Gündüz, (1966), Batıya Yönelirken Şinasi, DTCF yay. Ank.

Akyüz, Kenan, (1986), Batı Tesirinde Türk Şiiri Antolojisi, İnkılap Kitapevi, İst.

Akyüz, Kenan, (1990), Modern Türk Edebiyatının Ana Çizgileri, İnkılâp Kitapevi, İst.,

Aydın, Abdulhalim, (2001), "Şinasi’nin Şair Evlenmesi’nde Fransız Etkisi” Firat Üniversitesi Sosyal Bilimler Dergisi, Cilt: 11, S.1.

Aydın, Abdulhalim, (2000), Batılılaşma Döneminde Şinasi ve Fransız Etkisi, Hacettepe Üniversitesi Edebiyat Fakültesi Dergisi Cilt: 17 / Sayı: 2.

Banarlı, Nihad Sami, (1998), Resimli Türk Edebiyatı Tarihi C.II, MEB. Yay., İst.

Ekiz, Osman Nuri, (1985), Şinasi, Kastaş yay., İst.

Hizarcı, Suat, (1955), Tanzimat Edebiyatı Antolojisi, Varlık yay., İst. 
F.Ü. Sosyal Bilimler Dergisi 2017-27/2

Kanter, M. Fatih, (2001), Şinasi'nin Şiirinde Yeni İnsan Tipi, Türk Kültürü, Ekim.

Kaplan Mehmet, (1999), "Şinasi'nin Türk Şiirinde Yaptı̆̆ı Yenilik”, Türk Edebiyatı Üzerine Araştırmalar, İst.

Karabulut, Mustafa, (2016), Osmanlı Imparatorluğu'nda 19. Yüzyılda Değişim Süreci, Sosyal ve Kültürel Durum, Mecmua Dergisi,S. 16.

Karabulut, Mustafa, (2010), Tanzimat Dönemi'nde Osmanlının Yenilşeme Sürecine Bir Bakış, Türk Dünyası Araştırmaları, Sayı: 187, Ağustos, İstanbul.

Karal, Enver Ziya, "Tanzimattan Evvel Garplılaşma Hareketleri", Tanzimat I., Maarif Mtb. İst. 1940.

Karal, Enver Ziya, (1956), Osmanl Tarihi, C.VII. TTK Ank.

Köprülü, Fuat, (1989), Edebiyat Araşttrmaları I., Ötüken, İst.

Köprülü, Orhan, (1984), Türk Klasikleri, Dösar yay., İst.

Lanson, Gustave, (1936), Histoire de la Littérature Française, Hachette, Paris.

Levend, Agah Sırrı, (1934), Edebiyat Tarihi Dersleri-Tanzimat Edebiyatı, Marifet Mtb., İst.

Montesquieu, (1963), Kanunların Ruhu Üzerine, C.I., (Çev: Fehmi Baldaş), İst.

Okandan, Recai G., (1940), “Amme Hukukumuzda Tanzimat Devri”, Tanzimat I. Maarif Mtb. İst.

Okandan, Recai G., Tanzimattan Evvel Garplılaşma Hareketleri", Tanzimat I., Maarif Mtb. İst. 1940.

Özcan, Tarık, (2006), Şinasi'nin şiirinde Dil ve Üslup, Türk Dili Dil ve Edebiyat Dergisi, Ekim.

Perin, Cevdet, Tanzimat Edebiyatında Fransız Tesiri, Pulhan Mat. , İst. 1946.

Seçmen, Hüseyin, (1972), Şinasi, TDK, yay, Ank.

Siyavuşgil, Sabri Esat, (1940), "Tanzimat'ın Fransız Efkârı Umumiyesinde Uyandırdığı Akisler", Tanzimat I., Maarif Mtb. İst. Ank.

Şinasi, (1960), Makaleler, Külliyat, IV. Baskıya hazırlayan Fevziye Abdullah Tansel, Dün-Bugün yay.,

Şinasi, (1960), Müntabahat-ı Eş'ar, Hazırlayan : Süheyl Beken, Dün-Bugün Yay., Ankara.

Tanpınar, Ahmet Hamdi, (1997), 19. Asır Türk Edebiyatı Tarihi, Çağlayan Kitabevi, İst.

Ülken, Hilmi Ziya, (1998), Türkiye'de Çağdaş Düşünce Tarihi, Ülken Yay., İst.

Vardar, Berke, (1972), Fransız Edebiyatt, Dönem Yay., C.III, İst.

Voltaire, (1839), Les Cabales, in Euvres de Voltaire, P. Pourrat Freres Ed., Paris.

Voltaire, (1839), Traité de Philosophie, in Oeuvres de Voltaire, P. Pourrat Freres Ed., Paris.

Yahya Kemal, (1990), Edebiyata Dair, İstanbul Fetih Cemiyeti Yay., İst. 